\title{
Development of Natural Killer Cytotoxicity during Childhood: Marked Increases in Number of Natural Killer Cells with Adequate Cytotoxic Abilities during Infancy to Early Childhood
}

\author{
AKIHIKO YABUHARA, HIROSHI KAWAI, AND ATSUSHI KOMIYAMA \\ Department of Pediatrics, Shinshu University School of Medicine, Mastumoto, Japan
}

\begin{abstract}
The cytotoxicity of natural killer (NK) cells against K562 cells and their responsiveness to interferon$\alpha$ and interleukin 2 (IL-2) were studied throughout childhood using ${ }^{51} \mathrm{Cr}$-release and single-cell assays. Although NK activity was extremely low in the neonatal period, it almost reached the adult level during 1 to 5 mo of age and remained at that level thereafter. At the single-cell level, the binding, lytic, and recycling abilities were also depressed in the neonatal period, but these abilities improved conspicuously after this period; in particular, the lysis and recycling were at higher levels during 6 mo to $4 \mathrm{y}$ of age. The absolute numbers of circulating cytotoxic NK cells were high during infancy to early childhood: they were 54 \pm 24 (mean $\pm \mathrm{SD} / \mathrm{mm}^{3}$ ) in neonates, $115 \pm 48$ in 1 - to 5mo-old infants, $121 \pm 42$ in 6- to 12 -mo-old infants, $93 \pm$ 26 in 1- to 4-y-old children, and $42 \pm 16$ in adults. Interferon- $\alpha$ and IL-2 could enhance NK activity throughout childhood. The IL-2 enhancement was prominent especially in the neonatal period; IL-2 yielded a 2.5 -fold increase in the number of cytotoxic cells and improved the recycling to the adult level. At older ages, interferon- $\alpha$ and IL-2 yielded 1.4- and 1.9-fold increases in the number of cytotoxic cells, respectively, but did not enhance the recycling. The increased number of NK cells with adequate cytotoxic abilities during infancy to early childhood indicates the predominance of $\mathrm{NK}$ immunity during these periods. IL-2 is a cytokine that induces high levels of NK cytotoxicity even in neonates. (Pediatr Res 28: 316-322, 1990)
\end{abstract}

\section{Abbreviations}

\author{
NK, natural killer \\ IFN, interferon \\ IL-2, interleukin 2 \\ E:T, effector:target \\ $\%$ TBC, percentage of target-binding cells \\ $\%$ DC, percentage of dead conjugates \\ MRC, maximal recycling capacity
}

Growing evidence indicates that NK cytotoxicity is a response to viral infection before the generation of antiviral antibody and cytotoxic T lymphocytes (1-3) and NK cells play an important role in the early protection against primary infections $(4,5)$. The

Received December 19, 1989; accepted May 15, 1990

Correspondence: Dr. Akihiko Yabuhara, Department of Pediatrics, Shinshu University School of Medicine, Asahi 3-1-1, Matsumoto, 390, Japan. virus exposure of neonates can result in severe infection, which is explained by the depressed activity of NK cells (5-8). Although viral infections cause various clinical pictures at different levels of ontology (9), very little is known about the developmental profile of NK cytotoxicity during childhood.

It is known that the number of lymphocytes in the peripheral blood varies widely among different ages of childhood. Nevertheless, NK activity usually represents the cytotoxicity of a given number of lymphocytes (2). Although morphologic examination and surface marker analysis have been commonly used to determine the number of NK cells $(2,10)$, there have been conflicting reports regarding the relationship between the NK cell number and NK activity; the percentages of large granular lymphocytes and $\mathrm{CD} 16^{+}$cells in neonates are similar to those in adults $(11$, $12)$, but NK activity is depressed in neonates $(6,13,14)$. A singlecell cytotoxicity assay allows the determination of the number of NK cells with cytotoxic abilities $(2,15)$.

The purpose of our study was to investigate the developmental profile of the cytotoxicity mediated by circulating NK cells during childhood using ${ }^{51} \mathrm{Cr}$-release and single-cell assays. In our study, we demonstrate the normalization of NK cell functions after the neonatal period and an increased number of the cells during infancy to early childhood.

\section{MATERIALS AND METHODS}

Subjects. Cord blood samples were collected immediately after delivery of normal full-term newborns; all babies were born of healthy mothers with uncomplicated pregnancy and delivery. The blood of full-term newborn infants was obtained from the peripheral artery when partial exchange transfusions were performed during 1 to $3 \mathrm{~d}$ of life because of polycythemia; these infants were also born of healthy mothers with uncomplicated pregnancy and did not have an associated condition such as Down's syndrome or congenital adrenal hyperplasia. Peripheral venous blood samples were obtained from children ranging from 1 mo to 13 y of age who visited our hospital for examination for some immunodeficiency but proved to be free, and from healthy adults ranging from 21 to $30 \mathrm{y}$ of age.

Preparation of lymphocytes. Mononuclear cells were separated from the heparinized blood by Ficoll-Hypaque gradient centrifugation and depleted of adherent cells by incubation on plastic culture dishes. The nonadherent cells were resuspended in RPMI-1640 medium (Flow Laboratories, Irvine, Scotland) containing $10 \%$ heat-inactivated FCS and used as lymphocytes in this study.

Treatments of lymphocytes with IFN- $\alpha$ and IL-2. Lymphocytes $\left(1 \times 10^{6} / \mathrm{mL}\right)$ were incubated for $24 \mathrm{~h}$ in a humid atmosphere of $5 \% \mathrm{CO}_{2}$ at $37^{\circ} \mathrm{C}$ with medium alone, $1000 \mathrm{U} / \mathrm{mL}$ IFN- $\alpha$ (Kyowa Hakko Co., Tokyo, Japan) or $200 \mathrm{U} / \mathrm{mL}$ recombinant IL-2 (Takeda Seiyaku Co., Osaka, Japan). After incubation, the 
cells were washed once and used as effector cells in cytotoxicity assays.

Assay for NK activity. NK activity was measured in a $4-\mathrm{h}{ }^{51} \mathrm{Cr}$ release assay using K562 target cells as previously described (16). Briefly, effector cells were mixed with ${ }^{51} \mathrm{Cr}$-labeled $\mathrm{K} 562$ cells (1 $\times 10^{4}$ ) in a total volume of $200 \mu \mathrm{L}$ in the wells of roundbottomed microtiter plates (Nunc, Roskilde, Denmark) at an E:T ratio of $5: 1$ or $20: 1$, and the cells were incubated for $4 \mathrm{~h}$ at $37^{\circ} \mathrm{C}$ in a $5 \% \mathrm{CO}_{2}$ atmosphere. After incubation, the plates were centrifuged, and $100 \mu \mathrm{L}$ of the supernatant were harvested and assayed for radioactivity. NK activity, expressed as \% cytotoxicity, was calculated by the following formula: $\%$ cytotoxicity $=$ [(experimental release - spontaneous release)/(total release spontaneous release)] $\times 100$.

Estimation of $V_{\max }$. The maximum NK potential $\left(\mathrm{V}_{\max }\right)$ of effector cells was determined by a modification of the method of Ullberg and Jondal (15). Inasmuch as the dose-response curve from the ${ }^{51} \mathrm{Cr}$-release assay resembled Michaelis-Menten enzymesubstrate kinetics, the $V_{\max }$ values could be determined using Lineweaver-Burk plots. Briefly, $10^{5}$ effector cells in $100 \mu \mathrm{L}$ were incubated for $4 \mathrm{~h}$ in round-bottom microtiter wells with $100 \mu \mathrm{L}$ of ${ }^{51} \mathrm{Cr}$-labeled K562 cells at six doubling dilutions, from $4 \times 10^{5}$ to $1.25 \times 10^{4}$ cells per well. The values of $\%$ cytotoxicity were calculated for each target cell concentration as described above. The number of killed target cells was determined by multiplying the initial number of target cells by $\%$ cytotoxicity. The $V_{\max }$ of $10^{5}$ effector cells was determined from a linear regression curve obtained by plotting the reciprocals $1 / \mathrm{V}$ (ordinate) and $1 / \mathrm{T}$ (abscissa), where $\mathrm{V}$ is the number of killed target cells and $\mathrm{T}$ is the initial number of target cells. The $\mathrm{V}_{\max }$ was obtained from the reciprocal of the intercept of the curve with the ordinate and represents the maximum number of target cells that can be killed by $10^{5}$ effector cells (Fig. $1 \mathrm{~A}$ ).

Subsequently, we simplified this procedure by finding that the obtained $\mathrm{V}_{\max }$ values correlated well with the corresponding values from a $4-\mathrm{h}{ }^{51} \mathrm{Cr}$-release assay at an E:T ratis of $5: 1$ (\% cytotoxicity in 5:1) as described by Ullberg and Jondal (15). As shown in Fig. $1 B$, there was a linear correlation between the two values $(r=0.959)$. Therefore, it was possible to get rough estimation of the $V_{\max }$ values using the ${ }^{51} \mathrm{Cr}$-release assay. The $\mathrm{V}_{\max }$ values were calculated using the following formula: $\mathrm{V}_{\max }=$ $1.9 \times 10^{3}+4.0 \times 10^{2} \times \%$ cytotoxicity in $5: 1$.

Single-cell cytotoxicity assay in agarose. This assay was performed according to the method of Ullberg and Jondal (15) with some modifications (17). Briefly, equal numbers of effector cells and unlabeled K562 target cells $\left(2 \times 10^{5}\right)$ were mixed in a total volume of $200 \mu \mathrm{L}$ RPMI- 1640 with $10 \%$ FCS, centrifuged at 250 $\times g$ for $5 \mathrm{~min}$, and incubated at $37^{\circ} \mathrm{C}$ for $10 \mathrm{~min}$. The resulting pellet was gently resuspended by Pasteur pipetting 10 times and the resuspended cells were then carefully added to $0.5 \%$ agarose in RPMI-1640, which had been precooled from $48^{\circ} \mathrm{C}$ to $39^{\circ} \mathrm{C}$. The cells were mixed with a Pasteur pipette and immediately poured onto culture plates precoated with $0.5 \%$ agarose. After solidifying, the plates were overlayered with culture medium and incubated at $37^{\circ} \mathrm{C}$ for $4 \mathrm{~h}$. After the medium was removed, the plates were stained with $0.1 \%$ trypan blue for $5 \mathrm{~min}$, washed with PBS, and fixed with $1 \%$ formaldehyde. Control plates of target cells alone were prepared in an identical manner.

The plates were examined under a microscope. The \% TBC was determined by counting the number of lymphocytes bound to target cells in 400 lymphocytes. The percentage of dead target cells in the conjugates was determined by counting the number of trypan blue-positive target cells in 100 conjugates. The percentage of spontaneously dead target cells was determined by counting the number of trypan blue-positive cells in 100 target cells on control plates. Corrections were made using the following formula to calculate the \% DC: \% DC $=$ (percentage of dead target cells in conjugates) - (percentage of spontaneously dead target cells) $\times$ (percentage of dead target cells in conjugates).

Estimation of percentage of cytotoxic cells and MRC. The percentage of cytotoxic cells was estimated from the single-cell cytotoxicity assay by multiplying \% TBC by $\%$ DC. The cytotoxic cells represent the cells that have both binding and lytic abilities against K562 cells. When lymphocytes were untreated, they were defined as cytotoxic NK cells. MRC, which is an estimation of the average number of target cells killed by each cytotoxic cell
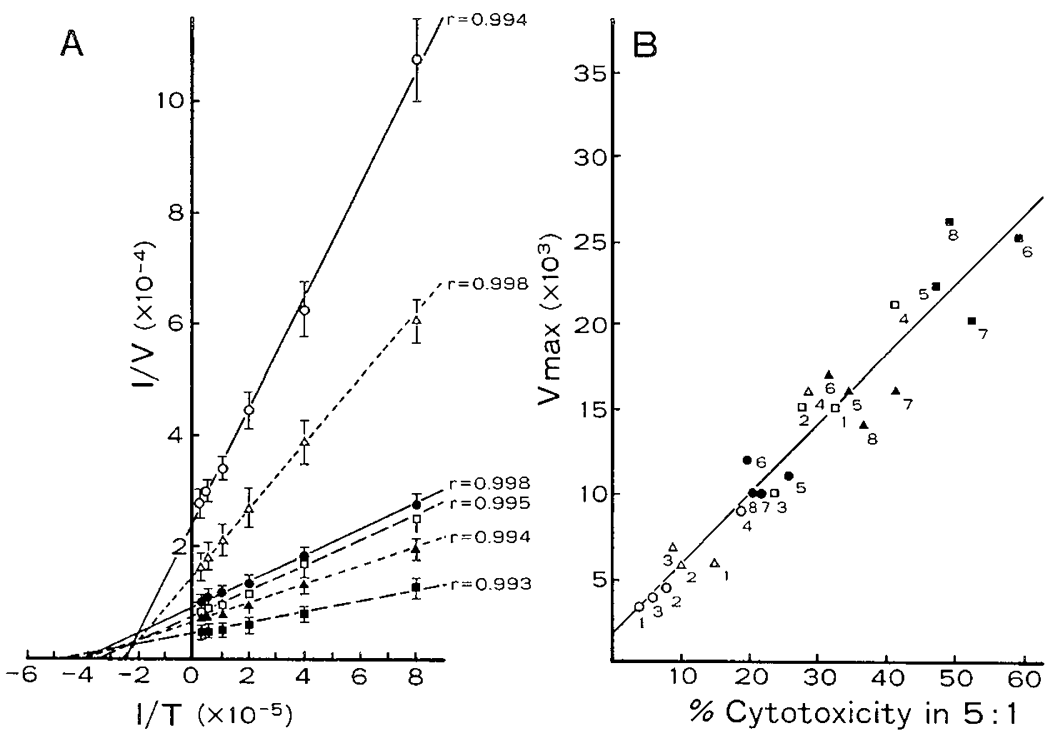

Fig. 1. A, Lineweaver-Burk plots of NK activity mediated by lymphocytes from cord blood and adult peripheral blood. Lineweaver-Burk plots were drawn as described in Materials and Methods to calculate $\mathrm{V}_{\max }$ and $\mathrm{Km}$. $\mathrm{V}_{\max }$ equals the reciprocal of the intercept with the ordinate and $\mathrm{Km}$ equals the negative reciprocal of the intercept with the abscissa. The values of $\mathrm{V}_{\max }$ and $\mathrm{Km}$ were $4.1 \pm 0.3$ and $4.1 \pm 0.2$ (untreated cord lymphocytes, O), $6.6 \pm 1.1$ and $3.9 \pm 0.6$ (IFN- $\alpha$-treated cord lymphocytes, $\Delta$ ), $12.9 \pm 3.5$ and $2.9 \pm 0.8$ (IL-2-treated cord lymphocytes, $\square$ ), $10.8 \pm 1.5$ and 2.5 \pm 0.4 (untreated adult lymphocytes, $\bullet$ ), $15.0 \pm 2.5$ and $2.5 \pm 0.5$ (IFN- $\alpha$-treated adult lymphocytes, $\mathbf{\Delta}$ ), and $22.1 \pm 5.6$ and $2.2 \pm 0.8$ (IL-2 treated adult lymphocytes, $\mathbf{a})$. Data are expressed as mean $\pm \mathrm{SD}$. B, correlation between $\mathrm{V}_{\max }$ and \% cytotoxicity in 5:1. Lymphocytes obtained from three cords $(I-3)$, a 5 -y-old child (4), and four adults $(5-8)$ were cultured with medium alone $(0, \bullet), 1000 \mathrm{U} / \mathrm{mL}$ IFN- $\alpha(\Delta, \mathbf{\Delta})$, or $200 \mathrm{U} / \mathrm{mL}$ IL-2 $(\square$,

D). Values from the ${ }^{51} \mathrm{Cr}$-release assay at an E:T ratio of 5:1 (\% cytotoxicity in 5:1) are plotted against the corresponding $\mathrm{V}_{\max }$ values. This showed a good correlation between the two parameters $(r=0.959)$. 
in $4 \mathrm{~h}$, was calculated by dividing the $V_{\max }$ by the absolute number of cytotoxic cells among $10^{5}$ effector cells.

Surface marker analysis. Surface markers of lymphocytes from cord and peripheral blood were analyzed in an EPICS V flow cytometer (Coulter Electronics, Inc., Hialeah, FL) using FITCconjugated OKM1 (Ortho Diagnostic Inc., Raritan, NJ), antiLeu-7, anti-Leu-11a (Becton Dickinson, Parsippany, NJ) and phycoerythrin-conjugated NKH1 (Coulter Immunology, Hialeah, FL) monoclonal antibodies.

Estimation of numbers of cytotoxic cells and NK-associated antigen-positive cells. The absolute number of cytotoxic cells was estimated by multiplying the percentage of the cells by the corresponding total number of lymphocytes. Similarly, the number of NK-associated antigen-positive cells was estimated by multiplying the percentage of the cells by the corresponding total number of lymphocytes.

Statistical analysis. Comparisons were done using $t$ test and correlations were computed using linear regression analysis by the least squares method.

\section{RESULTS}

NK activity. The results were analyzed by dividing them into eight periods: cord, $1-3 \mathrm{~d}, 1-5 \mathrm{mo}, 6-12 \mathrm{mo}, 1-4 \mathrm{y}, 5-8 \mathrm{y}, 9-13$ $y$, and adult (Fig. 2). NK activity was extremely depressed in the neonatal period, but it almost reached the adult level during 1 to $5 \mathrm{mo}$ of age and remained at that level thereafter. IFN- $\alpha$ and IL-2 enhanced NK activity in all periods of childhood; the enhancement by IL-2 was stronger than that by IFN- $\alpha$. In particular, the IL-2 enhancement was prominent in the neonatal period; however, the gross activity was still low compared with that at older ages or in adults.

$N K$ parameters for cytotoxic abilities. By using ${ }^{51} \mathrm{Cr}$-release and single-cell assays simultaneously, we were able to determine the NK parameters (Table 1). The $\mathrm{V}_{\max }$ values estimated by ${ }^{51} \mathrm{Cr}$ release assays at an $\mathrm{E}: \mathrm{T}$ ratio of $5: 1$ were almost equal to those obtained by Lineweaver-Burk plots (Fig. $1 \mathrm{~A}$ and Table 1). Although the \% TBC, which shows the percentage of lymphocytes capable of binding to K562 cells, was low in the neonatal period, it increased considerably after this period. Similarly, the \% DC, which shows the percentage of TBC exerting a lytic function, and estimated MRC values were low in the neonatal period;

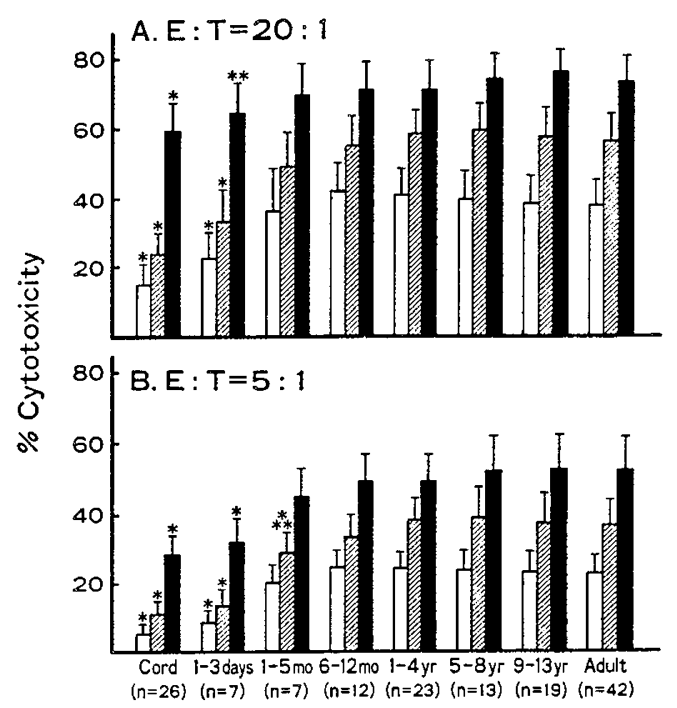

Fig. 2. NK activity and effects of IFN- $\alpha$ and IL-2 on NK activity during childhood. Lymphocytes were incubated for $24 \mathrm{~h}$ with medium alone (open column), $1000 \mathrm{U} / \mathrm{mL}$ IFN- $\alpha$ (shaded column), or $200 \mathrm{U} /$ mL IL-2 (closed column) and were evaluated for NK activity at E:T ratios of $20: 1(A)$ and $5: 1(B)$. The numbers of subjects are shown in parentheses. Data are expressed as mean $\pm \mathrm{SD} .{ }^{*}, p<0.001 ;{ }^{* *}, p<$ 0.01 ; and ${ }_{* *}^{*}, p<0.05$, as compared with the adult values. however, these values reached the maximal levels during $6 \mathrm{mo}$ to $4 \mathrm{y}$ of age and then remained at the adult levels. The percentage of cytotoxic NK cells, which represents the relative proportion of lymphocytes having cytotoxic ability against K562 cells, in neonates was only $50 \%$ of the adult value, but no difference was observed between children at older ages and adults. These results suggest that neonates have functionally immature NK cells, but the cytotoxic functions of NK cells develop conspicuously after the neonatal period.

The mechanism(s) of IFN- $\alpha$ or IL-2 enhancement of NK activity was analyzed at the single-cell level (Fig. 3). IL-2 increased the \% TBC at all periods of childhood, but IFN- $\alpha$ did not have such an effect at any period (Fig. $3 A$ ). The $\%$ DC was increased by both IFN- $\alpha$ and IL-2, but the degree of the increase by IL-2 was higher than that by IFN- $\alpha$ (Fig. $3 B$ ). Accordingly, IL-2 could increase the number of cytotoxic cells more efficiently than IFN- $\alpha$ (Fig. $3 C$ ); although IFN- $\alpha$ yielded a 1.4-fold increase in the number of the cells in all periods, IL-2 yielded a 2.5 -fold increase in the neonatal period and a 1.9-fold increase at older ages (Table 2). IL-2 increased the MRC values in the neonatal period; however, there was no IL-2-induced increase in the values at older ages (Fig. 3D). These results indicate that IL-2 has augmentative effects on functionally immature NK cells in neonates and can induce the cells to develop high levels of cytotoxicity.

Percentages of cytotoxic NK cells and NK-associated antigenpositive cells. As presented in Tables 1 and 2 , only about $1 \%$ of lymphocytes were cytotoxic NK cells in the neonatal period, but the percentage increased to about $2 \%$ after this period and then remained at this level.

The results from the surface marker analysis are shown in Table 2. The percentages of CD $11 \mathrm{~b}(\mathrm{OKM} 1)^{+}$cells and CD16(Leu-11a $)^{+}$cells were similar among all periods of childhood. The percentage of $\mathrm{CD} 56(\mathrm{NKH} 1)^{+}$cells was low only in the neonatal period as compared with that in adults; although this percentage appeared to be low during infancy to early childhood, the difference was not statistically significant. The correlation coefficient between the percentage of $\mathrm{CD}^{+} 6^{+}$cells and the value of $\mathrm{NK}$ activity at a 5:1 E:T ratio or the percentage of cytotoxic NK cells were 0.662 or 0.802 , respectively.

Numbers of cytotoxic cells and NK-associated antigen-positive cells. Because the number of lymphocytes varies widely among different ages of childhood, it is necessary to evaluate not only the percentage of NK cells but also their absolute number. The number of cytotoxic NK cells was extremely high during 1 mo to $4 \mathrm{y}$ of age. In comparison of neonates and adults, there was no appreciable difference in the number of cytotoxic NK cells, but when the lymphocytes were treated with IL-2, the gross number of cytotoxic cells was higher in the neonatal period (Table 3).

The numbers of $\mathrm{CD} 11 \mathrm{~b}^{+}$cells and $\mathrm{CD} 16^{+}$cells were high until $4 \mathrm{y}$ of age as compared with those in adults. The number of $\mathrm{CD} 6^{+}$cells appeared to be high during childhood, but the statistical significance was observed only during 1 to 12 mo of age. In contrast, the number of CD57(Leu-7 $)^{+}$cells increased gradually with age (Table 3 ).

\section{DISCUSSION}

NK cells have been defined as non-T, non-B lymphocytes capable of lysing virus-infected cells without prior sensitization $(1-3)$. Thus, NK cells are expected to have importance, especially at the early periods of childhood. NK activity in the neonatal period has been well studied $(4,6,12-14)$, and the depressed activity of NK cells appears to be related to susceptibility of severe viral infections (4-8). However, there are few precise studies on NK cytotoxicity during childhood. In mice, NK activity is absent at birth, reaches its maximum during the first 6 to $8 \mathrm{wk}$ of life, and decreases thereafter (18). Our present study has confirmed the low NK activity in neonates and has demon- 
Table 1. NK activity and NK parameters for cytotoxic abilities of normal subjects at different ages

\begin{tabular}{|c|c|c|c|c|c|c|c|c|}
\hline \multirow[b]{3}{*}{ Age } & \multirow{3}{*}{$\begin{array}{c}\text { Number of } \\
\text { subjects } \\
\text { (male, female) }\end{array}$} & \multirow{2}{*}{\multicolumn{2}{|c|}{$\frac{\% \text { Cytotoxicity* }}{\text { E:T ratios }}$}} & \multicolumn{5}{|c|}{ NK parameters $\dagger$} \\
\hline & & & & \multirow{2}{*}{$\begin{array}{l}\text { Estimated } \\
V_{\max }\left(\times 10^{3}\right)\end{array}$} & \multirow[b]{2}{*}{$\%$ ТВC } & \multirow[b]{2}{*}{$\% \mathrm{DC}$} & \multirow{2}{*}{$\begin{array}{c}\text { Estimated \% } \\
\text { cytotoxic NK cells }\end{array}$} & \multirow[b]{2}{*}{ Estimated MRC } \\
\hline & & $20: 1$ & $5: 1$ & & & & & \\
\hline Cord & $26(12,14)$ & $14.8 \pm 5.9 \ddagger \S$ & $5.3 \pm 2.7 \S$ & $4.0 \pm 1.1 \S$ & $6.2 \pm 0.6 \S$ & $17.3 \pm 3.3 \S$ & $1.1 \pm 0.2 \S$ & $3.8 \pm 0.9 \S$ \\
\hline $1-3 d$ & $7(3,4)$ & $22.3 \pm 7.7 \S$ & $8.4 \pm 3.5 \S$ & $5.3 \pm 1.4 \S$ & $6.4 \pm 0.5 \S$ & $20.1 \pm 2.5 \|$ & $1.3 \pm 0.2 \S$ & $4.1 \pm 0.6 \S$ \\
\hline $1-5 \mathrm{mo}$ & $7(4,3)$ & $36.1 \pm 12.3$ & $19.9 \pm 5.6$ & $9.8 \pm 2.2$ & $7.5 \pm 1.2 \|$ & $25.0 \pm 4.7$ & $1.9 \pm 0.4$ & $5.3 \pm 0.5$ \\
\hline $6-12 \mathrm{mo}$ & $12(7,5)$ & $41.8 \pm 8.9$ & $24.4 \pm 5.2$ & $11.7 \pm 2.1$ & $7.6 \pm 0.9 \|$ & $27.3 \pm 2.79$ & $2.1 \pm 0.4$ & $5.6 \pm 0.6^{* *}$ \\
\hline $1-4 y$ & $23(13,10)$ & $40.7 \pm 7.9$ & $24.1 \pm 5.0$ & $11.5 \pm 2.0$ & $8.1 \pm 0.8 \|$ & $26.5 \pm 2.91$ & $2.2 \pm 0.3$ & $5.4 \pm 0.4^{* *}$ \\
\hline $5-8 y$ & $13(5,8)$ & $39.6 \pm 8.2$ & $23.7 \pm 5.8$ & $11.4 \pm 2.3$ & $8.4 \pm 0.8$ & $25.3 \pm 3.1$ & $2.1 \pm 0.3$ & $5.4 \pm 0.6$ \\
\hline $9-13 y$ & $19(10,9)$ & $38.3 \pm 8.1$ & $22.9 \pm 6.2$ & $11.1 \pm 2.5$ & $8.6 \pm 0.9$ & $24.6 \pm 3.2$ & $2.1 \pm 0.3$ & $5.2 \pm 0.7$ \\
\hline Adult & $42(42,0)$ & $37.8 \pm 7.7$ & $22.6 \pm 5.5$ & $10.9 \pm 2.2$ & $8.8 \pm 0.9$ & $24.2 \pm 3.1$ & $2.1 \pm 0.3$ & $5.1 \pm 0.6$ \\
\hline
\end{tabular}

* Lymphocytes were incubated with medium alone for $24 \mathrm{~h}$ and were evaluated for cytotoxicity against $\mathrm{K} 562$ target cells.

$\dagger$ NK parameters were estimated by using a single-cell cytotoxicity assay in agarose in combination with a ${ }^{51} \mathrm{Cr}$-release assay at an E:T ratio of $5: 1$.

$\$$ Results are expressed as mean $\pm \mathrm{SD}$.

$\S$ Values are significantly $(p<0.001)$ lower than adult values.

$\|$ Values are significantly $(p<0.01)$ lower than adult values.

I Values are significantly $(p<0.01)$ higher than adult values.

** Values are significantly $(p<0.05)$ higher than adult values.
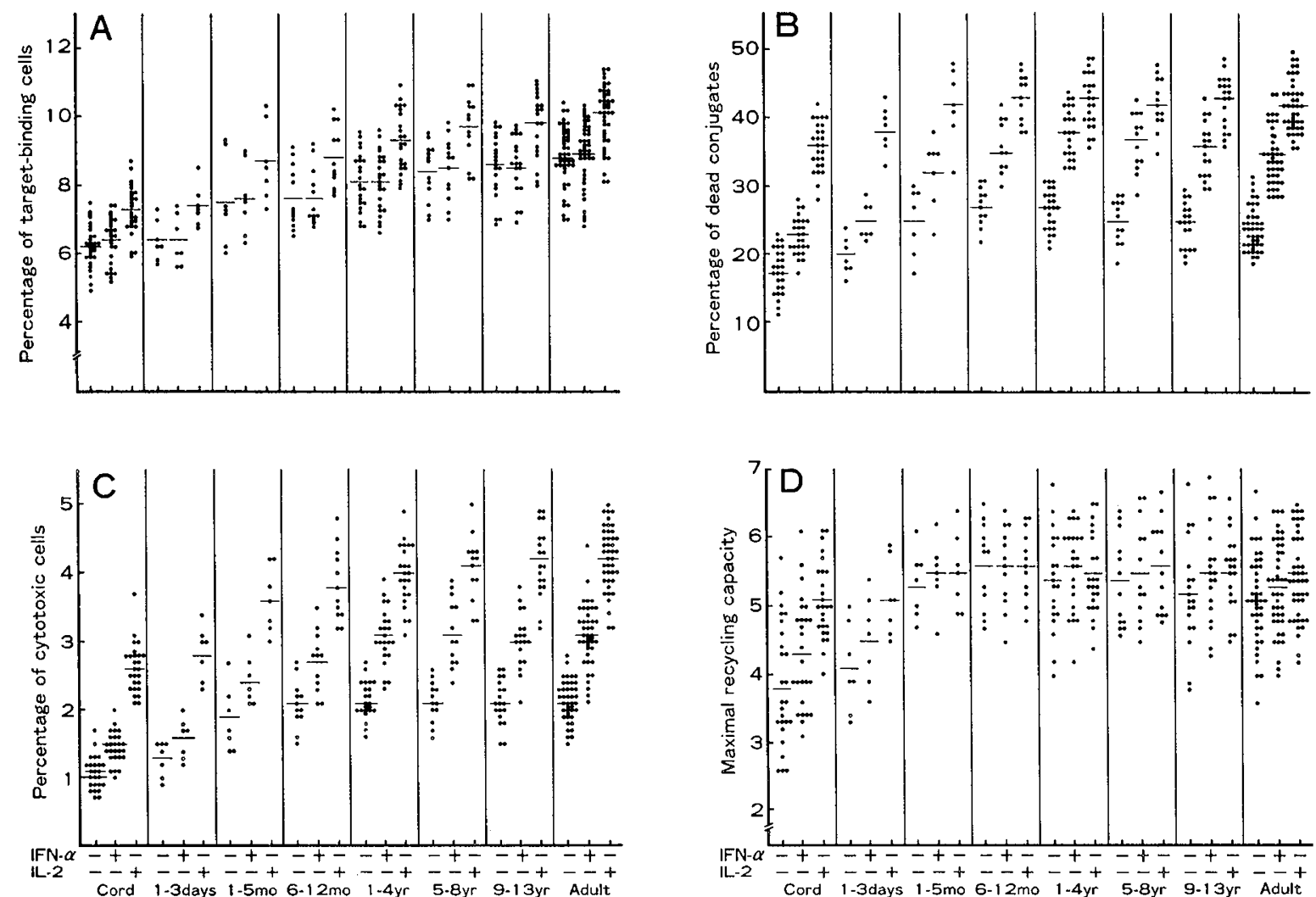

Fig. 3. Effects of IFN- $\alpha$ and IL-2 on NK parameters for cytotoxic abilities. Lymphocytes were incubated for $24 \mathrm{~h}$ with medium alone, $1000 \mathrm{U} /$

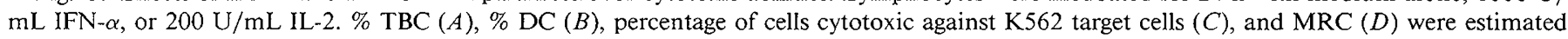
using a single-cell cytotoxicity assay and a ${ }^{51} \mathrm{Cr}$-release assay at a 5:1 E:T ratio. Each value obtained from these assays was plotted, and the mean values for each group were indicated by bars.

strated the normalization of NK activity after the neonatal period. These findings indicate that the cytotoxic functions of NK cells develop conspicuously at the early periods of childhood. With respect to the fact that adult females appear to have less NK activity than adult males (13), there was no such difference in children (data not shown).

NK cell cytolytic mechanisms consist of several steps (15): recognition of and binding to a target cell, lysis of the target, and repetition of this lytic sequence by recycling. Actually, several types of NK impairment have been recognized based on these mechanisms $(16,19-21)$. A single-cell cytotoxicity assay is useful to estimate the binding, lytic, and recycling abilities of cytotoxic effector cells and the relative proportion of the cells $(2,15)$. It is known that the cells displaying non-MHC-restricted cytotoxicity, commonly called NK activity, are heterogeneous $(10,22,23)$. Although there is a small amount of non-MHC-restricted cytotoxicity mediated by $\mathrm{CD}^{+} \mathrm{CD} 56^{+} \mathrm{T}$ cells with large granular lymphocyte morphology $(10,22)$, the main effector cells for NK activity are NK cells; about $95 \%$ of the total non-MHC-restricted cytotoxic activity is mediated by NK cells $(10,23)$. Therefore, the cytotoxic abilities of NK cells can be estimated using the single-cell assay. 
Table 2. Percentages of cells cytotoxic against $K 562$ cells and $N K$ cell-associated antigen-positive cells at different ages

\begin{tabular}{|c|c|c|c|c|c|c|c|c|}
\hline \multirow[b]{2}{*}{ Age } & \multirow{2}{*}{$\begin{array}{c}\text { Number of } \\
\text { subjects } \\
\text { (male, female) }\end{array}$} & \multicolumn{3}{|c|}{ Treatments ( $\%$ cytotoxic cells) ${ }^{*}$} & \multicolumn{4}{|c|}{ Surface markers ( $\%$ positive cells $) \dagger$} \\
\hline & & None & $\begin{array}{c}\text { IFN- } \alpha(1000 \\
\mathrm{U} / \mathrm{mL})\end{array}$ & $\begin{array}{c}\mathrm{IL}-2(200 \\
\mathrm{U} / \mathrm{mL})\end{array}$ & CD1 Ib (OKM1) & $\begin{array}{c}\text { CD16 } \\
\text { (Leu-11a) }\end{array}$ & CD56 (NKH1) & CD57 (Leu-7) \\
\hline Cord & $11(5,6)$ & $1.1 \pm 0.2 \ddagger \S$ & $1.4 \pm 0.2 \S$ & $2.6 \pm 0.3 \S$ & $20.8 \pm 4.3$ & $13.8 \pm 4.3$ & $9.1 \pm 4.3 \|$ & $1.2 \pm 0.7 \S$ \\
\hline $1-5 \mathrm{mo}$ & $6(3,3)$ & $1.8 \pm 0.5$ & $2.4 \pm 0.3 \pi$ & $3.5 \pm 0.4 \pi$ & $23.1 \pm 4.7$ & $12.7 \pm 4.6$ & $10.6 \pm 5.4$ & $1.4 \pm 0.8 \S$ \\
\hline $6-12 \mathrm{mo}$ & $7(4,3)$ & $2.0 \pm 0.4$ & $2.6 \pm 0.4$ & $3.8 \pm 0.5$ & $22.1 \pm 5.0$ & $12.5 \pm 4.9$ & $12.2 \pm 6.0$ & $1.7 \pm 1.5 \S$ \\
\hline $1-4 y$ & $8(5,3)$ & $2.1 \pm 0.3$ & $3.1 \pm 0.5$ & $4.0 \pm 0.6$ & $23.6 \pm 5.4$ & $12.9 \pm 4.6$ & $13.1 \pm 5.6$ & $2.6 \pm 1.9 \S$ \\
\hline $5-8 y$ & $6(3,3)$ & $2.1 \pm 0.3$ & $3.0 \pm 0.4$ & $3.9 \pm 0.4$ & $22.7 \pm 6.1$ & $14.4 \pm 5.2$ & $15.0 \pm 6.7$ & $12.5 \pm 6.7 \pi$ \\
\hline $9-13 y$ & $7(3,4)$ & $2.1 \pm 0.4$ & $3.1 \pm 0.4$ & $4.3 \pm 0.6$ & $23.4 \pm 6.2$ & $15.2 \pm 4.2$ & $16.5 \pm 5.9$ & $15.8 \pm 6.9$ \\
\hline Adult & $12(12,0)$ & $2.1 \pm 0.3$ & $3.0 \pm 0.5$ & $4.1 \pm 0.5$ & $23.1 \pm 6.8$ & $15.5 \pm 5.4$ & $16.4 \pm 6.5$ & $20.5 \pm 5.5$ \\
\hline
\end{tabular}

* Percentages of cytotoxic cells were estimated from a single-cell cytotoxicity assay in agarose using K562 cells as the target.

$\dagger$ Percentages of NK cell-associated antigen-positive cells were determined by an EPICS V flow cytometer (Coulter Electronics) using FITCconjugated OKM1 (Ortho Diagnostic Inc.), anti-Leu-7, anti-Leu-1 1a (Becton Dickinson), and phycoerythrin-conjugated NKH1 (Coulter Immunology) monoclonal antibodies.

$\ddagger$ Results are expressed as mean $\pm \mathrm{SD}$

$\S$ Values are significantly $(p<0.001)$ lower than adult values.

$\|$ Values are significantly $(p<0.01)$ lower than adult values.

I Values are significantly $(p<0.05)$ lower than adult values.

Table 3. Numbers of cells cytotoxic against $K 562$ target cells and NK cell-associated antigen-positive cells in cord and peripheral blood

\begin{tabular}{|c|c|c|c|c|c|c|c|c|c|c|}
\hline \multirow[b]{2}{*}{ Age } & \multirow{2}{*}{$\begin{array}{c}\text { Number } \\
\text { of } \\
\text { subjects } \\
\text { (male, } \\
\text { female) }\end{array}$} & \multirow[b]{2}{*}{$\begin{array}{c}\text { Leukocytes } \\
\left(\times 10^{3} /\right. \\
\left.\mathrm{mm}^{3}\right) \\
\end{array}$} & \multirow[b]{2}{*}{$\begin{array}{l}\text { Number of } \\
\text { lymphocytes } \\
\left(\times 10^{3} / \mathrm{mm}^{3}\right)\end{array}$} & \multicolumn{3}{|c|}{$\begin{array}{l}\text { Treatments [Number of cytotoxic } \\
\left.\text { cells }\left(/ \mathrm{mm}^{3}\right)\right]^{*}\end{array}$} & \multicolumn{4}{|c|}{ Surface markers [Number of positive cells $\left.\left(/ \mathrm{mm}^{3}\right)\right]^{*}$} \\
\hline & & & & None & $\begin{array}{l}\text { IFN- } \alpha(1000 \\
\mathrm{U} / \mathrm{mL})\end{array}$ & $\begin{array}{l}\text { IL-2 (200 } \\
\mathrm{U} / \mathrm{mL})\end{array}$ & $\begin{array}{l}\text { CD11b } \\
(\mathrm{OKM})\end{array}$ & $\begin{array}{c}\text { CD16 } \\
\text { (Leu-11a) }\end{array}$ & $\begin{array}{c}\text { CD56 } \\
\text { (NKH1) }\end{array}$ & $\begin{array}{c}\text { CD57 } \\
(\text { Leu-7) }\end{array}$ \\
\hline$c$ & $(5,6)$ & $.0 \pm 5.0 \dagger \ddagger$ & $51+5$ & $54+$ & & & $0 \ddagger$ & 709 & & \\
\hline & & & & $\ddagger$ & & & & & $8 \|$ & \\
\hline $6-12 \mathrm{mo}$ & $7(4,3)$ & 10. & & $121 \pm 42 \ddagger$ & & & & $00 \S$ & $95 \|$ & 10 भा \\
\hline $1-4 y$ & $8(5,3)$ & & & $\pm 26 \%$ & 136 & & $0 \ddagger$ & $64 \|$ & & \\
\hline $5-8 y$ & $6(3,3)$ & & & $63 \pm 13 \|$ & & & & & & \\
\hline $9-13 y$ & $7(3,4)$ & & & $57 \pm 19$ & & & & & & \\
\hline Adult & $12(12,0)$ & $6.8 \pm 1.6$ & $2.0 \pm 0.6$ & $42 \pm 16$ & $60 \pm 23$ & $82 \pm 30$ & $470 \pm 240$ & $318 \pm 191$ & $343 \pm 214$ & $400 \pm 150$ \\
\hline
\end{tabular}

* The number of cytotoxic cells was estimated by multiplying their percentage by the corresponding total number of lymphocytes. Similarly, the number of antigen-positive cells was estimated by multiplying their percentage by the corresponding total number of lymphocytes.

$\dagger$ Results are expressed as mean \pm SD

$¥$ The values are significantly $(p<0.001)$ higher than adult values.

$\S$ The values are significantly $(p<0.01)$ higher than adult values.

$\|$ The values are significantly $(p<0.05)$ higher than adult values.

I The values are significantly $(p<0.001)$ higher than adult values.

It is now apparent by our single-cell assay that the $\% \mathrm{TBC}, \%$ DC, and MRC values are low in the neonatal period. Considering that neonatal NK cells are normal in number as reported by Perussia $e$ t al. (11), the decreased \% TBC indicates low levels of target-binding ability of the cells. The lytic ability is also depressed in the neonatal period as confirmed at the single-cell level. The cytolysis by NK cells is conducted by releasing some lytic materials, e.g. NK cytotoxic factor (24) and perforin (25), from cytoplasmic granules, and neonatal NK cells have decreased numbers of cytoplasmic granules (26). Thus, neonatal NK cells possibly have smaller amounts of the lytic materials, which may explain the depressed lytic ability in the neonatal period. The low recycling ability is another characteristic of neonatal NK cells. The recycling depends on the time required to kill a target cell and the chemotactic mobility. A prolonged time for killing (12) may contribute to the low recycling ability, although the chemotactic mobility of neonatal NK cells remains unknown.

The low levels of the binding, lysis, and recycling of neonatal NK cells indicate that neonates have functionally immature NK cells. In this regard, after the neonatal period there is no marked difference between children and adults in the NK parameters. This finding confirms that the cytotoxic functions of NK cells develop during the early period of childhood. Accordingly, NK cells in children, except neonates, have adequate cytotoxic abilities. Of interest is that the \% DC and estimated MRC values are high during late infancy to early childhood, which indicates higher levels of NK cytotoxicity per cell during these periods. Although the clinical significance of this phenomenon is obscure, the elevated NK functions appear very advantageous considering the frequent exposure to primary viral infections during these periods (19).

NK activity usually represents the cytotoxicity of a given number of lymphocytes (2). Because the number of lymphocytes varies widely among different periods of childhood, to further understand NK immunity it is important to estimate the absolute number as well as the relative proportion of cytotoxic NK cells. In neonates, the number of cytotoxic NK cells is comparable to that in adults. Yet, the NK cell recycling is depressed in the neonatal period as demonstrated here. Accordingly, the depressed NK cytotoxicity in neonates, which may partly explain the deficient capacity to deal with viral infections (4-8), appears to result largely from the depressed recycling but not from the decrease in the number of cytotoxic NK cells.

It deserves discussion that there are increased numbers of NK cells with adequate cytotoxic abilities from 1 mo to $4 \mathrm{y}$ of age. This finding certainly indicates the predominance of NK immunity during infancy to early childhood. In this respect, it is well known that infants and young children are immunologically immature; they need a few years after birth for immunologic memory and full immunologic functions to develop (9). The 
high levels of NK cytotoxicity may make up for part of their immunologic immaturity; they may avoid some involvement in severe viral infections, inasmuch as NK cells function at an early stage of primary viral infections without prior sensitization (15). Indeed, NK cells appear to be required for the resistance to herpesvirus infections $(5,7)$, and herpesvirus exposure cannot result in severe infections after the neonatal period.

In dealing with the number of NK cells, we usually assess the cell surface phenotypes of lymphocytes. In this study, we have estimated the number of cells with CD11b, CD 16, CD56, or CD57 phenotype and have demonstrated that these cells, except for $\mathrm{CD}^{2} 7^{+}$cells, are increased during infancy to early childhood. This result indicates an increase in the number of NK cells during these periods, which is consistent with the result obtained from the single-cell assay. The CD56 phenotype is known to be a more specific indicator of cells involved in NK cytotoxicity $(10,27)$. In this respect, our study has shown that the percentage of CD $56^{+}$cells correlates with that of cytotoxic NK cells, but the correlation coefficient is not necessarily high. On the other hand, the CD57 antigen has been suggested to represent the cells previously stimulated in vivo (28) and to be nonspecific for NK cells (2). We thus feel that the gradual increase in $\mathrm{CD} 57^{+}$cells with age is reasonable.

Cytokines such as IFN and IL-2 are potent activators of NK cells $(2,4,6,12,14)$. Actually, NK activity can be enhanced by IFN- $\alpha$ and IL-2 throughout childhood. We thus examined the responsiveness of the cells to IFN- $\alpha$ and IL-2 at the single-cell level. In our study, IFN- $\alpha$ did not enhance the binding ability at any period but enhanced the lytic ability at all periods. This finding is in accordance with the previous report that IFN- $\alpha$ potentiates the cytotoxicity of previously nonlytic lymphocytes with binding ability, i.e. "pre-NK cells" (19). IL-2 is distinct from IFN- $\alpha$ in having augmentative effects not only on the lytic ability but also on the binding ability. Lymphocyte activation by IL-2 appears to increase the ability to adhere to a wide variety of cells $(29,30)$, which may give us an explanation for the enhancement of the binding ability. Furthermore, the enhancement of the lytic ability by IL- 2 is stronger than that by IFN- $\alpha$ at all periods. Accordingly, the higher responsiveness of NK cells to IL-2 may be explained by these mechanisms, at least after the neonatal period.

It is noteworthy that the IL-2 enhancement of NK activity is particularly prominent in the neonatal period. The IL-2-induced increase in the number of cytotoxic cells is higher in this period than that at older ages or in adults. In this respect, Seki et al. (12) have demonstrated that IL-2 greatly potentiates the cytotoxicity of the neonatal $\mathrm{CD}^{-} 6^{-}$subset. The high levels of IL-2 enhancement in the neonatal period may be partly explained by the heterogeneity of IL-2-sensitive cytotoxic cells, but this explanation is insufficient. Of importance is that IL-2 has another augmentative effect in the neonatal period; our study has demonstrated that IL-2 treatment can improve the NK cell recycling to the adult level. At the other periods, however, the recycling is not enhanced by IL-2. These findings indicate that the IL-2 improvement of recycling is characteristic of neonatal NK cells, and largely contributes to the high levels of IL-2 enhancement. The studies on IL-2 responsiveness have provided evidence that IL-2 can induce functionally immature NK cells to develop high levels of cytotoxicity in neonates.

In our study, we have demonstrated marked increases in the number of NK cells with adequate cytotoxic abilities during infancy to early childhood. Recent studies have revealed that the functions of NK cells are not restricted to cytotoxicity $(2,23)$; the cells are also involved in the regulation of antibody production (31), control of granulopoiesis (32), and production of cytokines (2). Little is known, however, about the relationship between these functions and the cytotoxic function. In any event, high levels of NK immunity during infancy to early childhood are very important because the NK cytotoxicity may make up for part of the immunologic immaturity in children at these periods.

\section{REFERENCES}

1. Herberman RB, Ortaldo JR 1981 Natural killer cells: their role in defense against disease. Science 214:24-30

2. Trinchieri G, Perussia B 1984 Human natural killer cells: biologic and pathologic aspects. Lab Invest 50:489-513

3. Casali P, Trinchieri G 1984 Natural killer cells in viral infection. In: AL Notkins, MB Oldstone (eds) Concepts in Viral Pathogenesis. Springer-Verlag, New York, pp 11-19

4. Kohl S, West MS, Loo LS 1988 Defects in interleukin-2 stimulation of neonatal natural killer cytotoxicity to herpes simplex virus-infected cells. J Pediatr 112:976-981

5. Wilson CB 1986 Immunologic basis for increased susceptibility of the neonate to infection. J Pediatr 108:1-12

6. Kohl S, Frazier JJ, Greenberg SB, Pickering LK, Loo LS 1981 Interferon induction of natural killer cytotoxicity in human neonates. J Pediatr 98:379384

7. Lopez C, Kirkpatrick D, Read SE, Fitzgerald PA, Pitt J, Pahwa S, Ching CY, Smithwick EM 1983 Correlation between low natural killing of fibroblasts infected with herpes simplex virus type 1 and susceptibility to herpes virus infections. J Infect Dis 147:1030-1035

8. Leibson PJ, Hunter-Laszlo M, Douvas GS, Hayward AR 1986 Impaired neonatal natural killer-cell activity to herpes simplex virus: decreased inhibition of viral replication and altered response to lymphokines. J Clin Immunol 6:216-224

9. Pabst HF, Kreth HW 1980 Ontogeny of the immune response as a basis of childhood disease. J Pediatr 97:519-534

10. Ortaldo JR, Longo DL 1988 Human natural lymphocyte effector cells: definition, analysis of activity, and clinical effectiveness. J Natl Cancer Inst 80:999-1010

11. Perussia B, Starr S, Abraham S, Fanning V, Trinchieri G 1983 Human natural killer cells analyzed by B73.1, a monoclonal antibody blocking Fc receptor functions. I. Characterization of the lymphocytes subset reactive with B73.1. $\mathrm{J}$ Immunol 130:2133-2141

12. Seki H, Ueno Y, Taga K, Matsuda A, Miyawaki T, Taniguchi N 1985 Mode of in vitro augmentation of natural killer cell activity by recombinant human interleukin 2: a comparative study of Leu-1 $11^{+}$and Leu-1 $11^{-}$cell populations in cord blood and adult peripheral blood. J Immunol 135:2351-2356

13. Uksila J, Lassila O, Hirvonen T 1982 Natural killer cell function of human neonatal lymphocytes. Clin Exp Immunol 48:649-654

14. Ueno Y, Miyawaki T, Seki H, Matsuda A, Taga K, Sato H, Taniguchi N 1985 Differential effects of recombinant human interferon- $\gamma$ and interleukin 2 on natural killer cell activity of peripheral blood in early human development. J Immunol 135:180-184

15. Ullberg M, Jondal M 1981 Recycling and target binding capacity of human natural killer cells. J Exp Med 153:615-628

16. Komiyama A, Kawai $H$, Yamada $S$, Aoyama $K$, Yamazaki M, Saito $H$ Miyagawa Y, Akabane T, Uehara Y 1985 Impaired natural killer cell recycling in childhood chronic neutropenia with morphological abnormalities and defective chemotaxis of neutrophils. Blood 66:99-105

17. Grimm E, Bonavida B 1979 Mechanism of cell-mediated cytotoxicity at the single cell level. I. Estimation of cytotoxic T lymphocytes frequency and relative lytic efficiency. J Immunol 123:2861-2869

18. Herberman RB, Nunn ME, Lavrin DH 1975 Natural cytotoxic reactivity of mouse lymphoid cells against syngeneic and allogeneic tumors. I. Distribution of reactivity and specificity. Int $\mathbf{J}$ Cancer 16:216-229

19. Katz P, Zaytoun AM, Fauci AS 1982 Deficiency of active natural killer cells in the Chediak-Higashi syndrome: localization of the defect using a single cell cytotoxicity assay. J Clin Invest 69:1231-1238

20. Kawai H, Komiyama A Aoyama K, Miyagawa Y, Akabane T 1988 Absence of circulating natural killer (NK) cells in a child with erythrophagocytic lymphohistocytosis lacking NK cell activity. Am J Hematol 28:107-112

21. Komiyama A, Kawai H, Yabuhara A, Yanagisawa M, Miyagawa Y, Ota M Hasekura H, Akabane 1990 Natural killer cell immunodeficiency in siblings: defective killing in the absence of natural killer cytotoxic factor activity in natural killer and lymphokine-activated killer cytotoxicities. Pediatrics 85:323-330

22. Lanier LL, Phillips JH, Hackett J, Tutt M, Kuwar V 1986 Natural killer cells: definition of a cell type rather than a function. J Immunol 137:2735-2739

23. Reynolds CW, Ortaldo JR 1987 Natural killer activity: the definition of a function rather than a cell type. Immunol Today 8:172-174

24. Bonavida B, Wright SC 1986 Role of natural killer cytotoxic factors in the mechanism of target-cell killing by natural killer cells. J Clin Immunol 6:18

25. Shinkai X, Takio K, Okumura K 1988 Homology of perforin to the ninth component of complement (C9). Nature 334:525-527

26. Abo T, Miller CA, Gartland GL, Balch CM 1983 Differentiation stages of human natural killer cells in lymphoid tissues from fetal to adult life. J Exp Med 157:273-284

27. Lanier LL, Le AM, Civin CI, Loken MR, Phillips JH 1986 The relationship of CD16 (Leu-11) and Leu-19 (NKH-1) antigen expression on human peripheral blood NK cells and cytotoxic $T$ lymphocytes. J Immunol 136:4480-4486

28. Phillips JH, Lanier LL 1985 A model for the differentiation of human natura 
killer cells: studies on the in vitro activation of Leu- $11^{+}$granular lymphocytes with a natural killer-sensitive tumor cell, K562. J Exp Med 161:1464-1482 29. Rothlein R, Springer TA 1986 The requirement for lymphocyte functionassociated antigen 1 in homotypic leukocyte adhesion stimulated by phorbol ester. J Exp Med 163:1132-1149

30. Nishimura T, Yagi H, Hashimoto Y 1987 The role of lymphokine-activated cell-associated antigen. II. Distribution and correlation with cell cycle. Cell Immunol 107:24-31
31. Targan S, Brieva J, Newman W, Stevens R 1985 Is the NK lytic process involved in the mechanism of NK suppression of antibody-producing cells? J Immunol 134:666-669

32. Herrmann F, Schmidt RE, Ritz J, Griffin JD 1987 In vitro regulation of human hematopoiesis by natural killer cells: analysis at a clonal level. Blood 69:246254

\section{Announcements}

\section{Annual Meeting}

The Society for Adolescent Medicine

The Society for Adolescent Medicine will hold its annual meeting in Denver, Colorado, March 14-17, 1991 at the Marriott City Center Hotel. The theme for the meeting will be "Adolescence and the Family" and it will address new material on a broad range of issues important to adolescent physical and emotional health. Topics include AIDS, teenage sexuality and pregnancy, eating disorders, depression, and drug and alcohol use. CME/ CEU credit is available. For further information, contact: The Society for Adolescent Medicine, Suite 120, 19401 East 40 Highway, Independence, MO 64055, (816) 795-8336.

\section{Call for Abstracts}

The American Pediatric Society and The Society for Pediatric Research announce that the abstract deadline for the 1991 Annual Meeting (April 29-May 2, 1991, New Orleans Hilton and Rivergate Convention Center, New Orleans, LA) has been set as January 3, 1991. For further information, contact: 2650 Yale Blvd., S.E., Suite 104, Albuquerque, NM 87106, (505)764-9099, FAX (505)842-8227. 